\title{
A Community Based Cross-Sectional Study to Find Out The Factors For The Delay in Diagnosis Of MDR-TB Cases Registered Under RNTCP in Krishna District, Andhra Pradesh
}

\author{
Madala $\mathrm{P}^{1}$, Jonnalagadda $\mathrm{RK}^{2}$, Sastry $\mathrm{TVSN}^{3}$, Samyukta $\mathrm{R}^{4}$, \\ N Hanumanth ${ }^{5}$, Raju $\mathrm{CN}^{6}$ \\ ${ }^{1}$ (Assistant Professor,Department Of Community Medicine, Dr. Pinnamaneni Siddhartha Institute Of Medical \\ Sciences And Research Foundation, Chinnoutpalli, Gannavaram, Krishna District, Andhra Pradesh) \\ ${ }^{2}$ (Professor \& HOD, Department Of Community Medicine, Dr PSIMS \& RF, Chinnoutpalli, Andhra Pradesh) \\ ${ }^{3}$ (District TB Control Officer, Krishna District, Andhra Pradesh) \\ ${ }^{4}$ (State TB Officer, Andhra Pradesh) \\ ${ }_{5}^{5}($ Lecturer In Statistics, Department Of Community Medicine, Dr PSIMS \& RF, Chinnoutpalli, Andhra Pradesh) \\ ${ }^{6}$ (Medical Officer, PP Unit, Kuppam,Chittoor District, Andhra Pradesh)
}

\begin{abstract}
:
Background: The economic burden to manage Multi-drug resistant Tuberculosis (MDR-TB) cases is very high as the average cost of drugs alone for treating MDR-TB patient is 50 to 200 times higher than for treating a drug-susceptible TB patient. If left undiagnosed or poorly treated, MDR-TB patients often live and suffer for years before succumbing to the disease and hence transmission of multi-drug resistance strains can continue, amplifying the multi-drug resistance in the community. Timely identification of MDR-TB cases and prompt initiation of treatment is crucial to prevent the transmission of disease and reduce the associated high morbidity and mortality. Hence, this study was conducted to find out the factors for the delay in diagnosis of MDR-TB Cases and the socio demographic factors among them.

Methodology: The present study was a Community based Cross-sectional study conducted among the TB Patients registered under RNTCP in all the 9 Tuberculosis Units (TUs) of Krishna District, Andhra Pradesh from November 2012 to October 2014. The total number of study participants that were interviewed were 97 based on inclusion and exclusion criteria .The perceptions of patients and Key staff of District TB Office, Krishna District have also been obtained regarding diagnostic delay.

Results: Males were 68\% of the total subjects and most (68\%) of them belong to "rural" background. Most (85\%) of the study subjects belong to the lower Socio-Economic Status (SES). Majority (81\%) of the study subjects belong to the "Hindu Religion". About 35\% of MDR-TB patients belong to "Unskilled" occupation group while $31 \%$ belong to "Unemployed" occupation group. Majority of the study subjects were "married" $(88 \%)$ in the study. The educational status was below primary level in $71 \%$ of them. The factors that were found statistically significant for diagnostic delay were long distance of Sputum collection centre (SCC) from patients residence; existence of co-morbid illness, alcoholism, low education level, lower SES and lack of family support. Conclusion: The factors associated with diagnostic delay were long distance of SCC from patients residence; existence of co-morbid illness, alcoholism, low education level, lower SES and lack of family support.
\end{abstract}

Keywords: MDR-TB, diagnosis, patient delay, health system delay.

\section{Introduction}

Globally, Tuberculosis (TB) remains a major health problem. It causes morbidity among millions of people each year and ranks as the second leading cause of death from an infectious disease .There are an estimated 8.6 million people who developed TB and 1.3 million died from this disease in 2012, of which, India alone accounts for $26 \%$ of the total cases .According to the WHO, there are an estimated new cases of about 450 000 of MDR-TB that occur worldwide every year and an estimated 170000 deaths from MDR-TB annually. Only 5\% of new bacteriological-confirmed TB cases and $9 \%$ of those previously treated for TB were tested for MDR-TB in 2012. The proportion of new cases with Drug Susceptibility Testing (DST) results has increased slightly in recent years but remains below the target envisaged for 2012 by the Global Plan to Stop TB 20112015. The MDR-TB high burden countries were able to detect less than $25 \%$ of their total estimated cases ${ }^{1}$.

In India, the estimated prevalence of MDR-TB is found to be 1 to $3 \%$ in new cases and around $12 \%$ in previously treated cases as per the Drug Resistance Surveillance (DRS) studies conducted by RNTCP countrywide ${ }^{2}$. India which is among the 27 MDR-TB high burden countries was able to detect only $26 \%$ of the total estimated cases ${ }^{1}$. 
Undiagnosed, untreated or improperly treated patients with MDR-TB are a source of ongoing transmission of resistant strains within the community, resulting in future added costs and mortality ${ }^{(3)}$. If left undiagnosed or poorly treated, MDR-TB patients often live and suffer for months to years before succumbing to the disease and hence transmission of multi-drug resistance strains can continue, amplifying the multi-drug resistance in the community ${ }^{3}$.

Hence, timely identification of MDR-TB cases and prompt initiation of treatment is crucial to prevent the transmission of disease and reduce the associated high morbidity and mortality ${ }^{3}$. As a very few studies have been conducted to find out the delay in diagnosis of MDR-TB cases in India, and none of the study of this kind was done in Krishna District, Andhra Pradesh (AP), this study was done to identify the various factors responsible for the delay in diagnosis of MDR-TB cases in Krishna District, AP.

\section{Objectives of the Study}

1. To identify the factors (both the patient and health system related factors) leading to the delay in diagnosis of MDR-TB cases.

2. To determine the socio-demographic factors among the study participants.

\section{Methodology}

The present study was a Community Based Cross Sectional Study conducted for a period of 24 months from November 2012 to October 2014 among the TB Patients registered under RNTCP in all the 9 Tuberculosis Units (TUs) of Krishna District, Andhra Pradesh. Inclusion Criteria being the patients who were registered during the above specified period, who were found to be having MDR-TB and those who have been initiated on treatment. Exclusion Criteria being patients in whom death was reported and those who have opted out for private treatment or those patients who were below 14 years of age. The total number of study participants that were interviewed was 97 and the perceptions of patients and Key staff of District TB Office, Krishna District regarding the delay of diagnosis have also been obtained. The study has obtained ethical clearance from Institutional Ethical Committee of Dr Pinnamaneni Siddhartha Institute of Medical Sciences \& Research Foundation, Chinnoutpalli, Krishna District, AP. Prior permission was obtained from District TB Control Officer, Krishna District, AP before the commencement of the study. Informed verbal consent of all study subjects was taken to confirm their willingness regarding participation in the study and the data that obtained was kept highly confidential.

\section{Case Definitions:}

MDR-TB suspect: A patient suspected of drug-resistant tuberculosis, based on RNTCP criteria, for submission of specimens for drug-susceptibility testing ${ }^{4}$

Table 1: MDR-TB suspect criteria

\begin{tabular}{|c|c|}
\hline MDR-TB SUSPECT CRITERIA & TYPE OF CASES TO BE INCLUDED \\
\hline \multirow[t]{3}{*}{ Criteria A } & All failures of new $T B$ cases $(1 A)$ \\
\hline & $\begin{array}{l}\text { Smear }+v e \text { previously treated cases who remain smear }+ \text { ve at } 4 \text { th month } \\
\text { or later }(2 A)\end{array}$ \\
\hline & All Pulmonary TB cases who are contacts of known MDR-TB Case (3A) \\
\hline \multirow[t]{2}{*}{ Criteria B (includes Criteria A) } & All smear + ve previously treated pulmonary $T B$ cases at diagnosis $(4 B)$ \\
\hline & Any smear + ve follow up result in new or previously treated cases $(5 B)$ \\
\hline \multirow[t]{2}{*}{ Criteria C(includes Criteria A \& B) } & All smear -ve previously treated pulmonary TB cases at diagnosis (6C) \\
\hline & HIV TB co-infected cases at diagnosis (7C) \\
\hline
\end{tabular}

Source: RNTCP PMDT guidelines (2012)

The Krishna District has adopted and following the "Criteria C" for the identification of MDR-TB suspects from October'2012.

Definition of MDR-TB Case: A TB patient whose sputum is culture positive for Mycobacterium tuberculosis and is resistant in-vitro to isoniazid and rifampicin with or without other anti-tubercular drugs based on DST results from an RNTCP-certified Culture \& Drug Susceptibility Testing (C\&DST) Laboratory.

In addition to this definition, if the C\&DST results of MDR-TB suspects show "any Rifampicin resistance", then they should also be managed the same way as MDR-TB cases even if they do not formally qualify as MDR-TB case as per the above definition and hence those cases have also been taken into consideration $^{4}$.

Diagnostic Delay: The duration between the line-listing of MDR-TB suspects and the confirmation of multi-drug resistance (i.e., resistance to atleast Isoniazid and Rifampicin drugs) at the RNTCP certified C\&DST laboratory, which should be within 14 days, beyond which, it is considered as diagnostic delay ${ }^{3}$. 
Data Variables and their Source in Parenthesis are TB Registration Number (TB Register), Number of MDR-TB suspects (Line-lists from Senior TB Laboratory Supervisor (STLS)), HIV Status ( Line-lists from STLS , RNTCP Referral for C \& DST Register maintained at District TB Centre for diagnosis and Follow up), Number of MDR-TB suspects referred for culture and DST (RNTCP Referral for C \& DST Register for diagnosis and Follow up) and Number of MDR-TB suspects diagnosed as MDR-TB confirmed case (RNTCP Referral for C \& DST Register for diagnosis and Follow up).

Piloting of the Study: In the month of October i.e., one month prior to the actual data collection period, a pilot study was conducted on a sample of 10 subjects to examine the feasibility of the questionnaire and for any incorporation that can be made in the questionnaire. Results of pilot study did not show any major alterations.

The Study Variables were broadly sub-divided into 3 groups, the first being socio demographic Variables, the second being Clinical Profile and the third being Factors studied for the delay in diagnosis. Data Validation was done by cross checking from various records for the same variable so that record errors can be minimized. Data was entered in MS Excel 2007 and then imported to SPSS Version 20 and later analyzed by applying the descriptive statistics and Chi-square test.

\section{Results}

Fig 1: Flow of MDR-TB patients in the current study

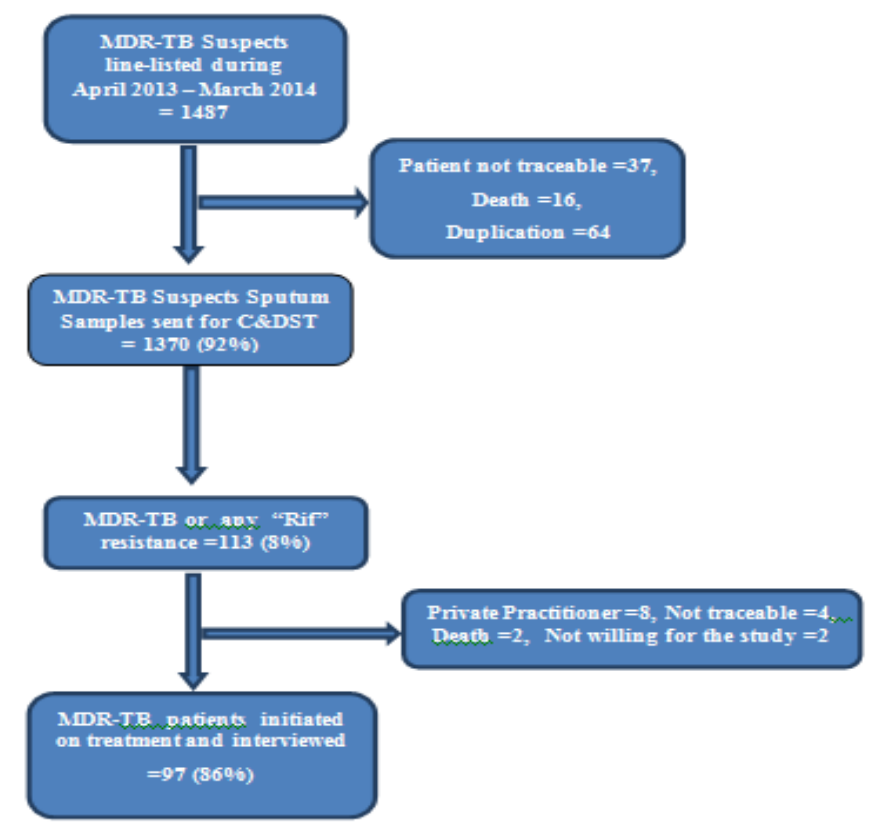

Table 2: Socio-demographic Factors of the study

\begin{tabular}{|l|c|c|}
\hline Socio-demographic Factor & Frequency & Percentage \\
\hline Gender & & \\
\hline Male & 66 & 68 \\
\hline Female & 31 & 32 \\
\hline Age & Frequency & Percentage \\
\hline $15-24$ yrs & 11 & 11 \\
\hline $25-34$ yrs & 17 & 18 \\
\hline $35-44$ yrs & 37 & 38 \\
\hline $45-54$ yrs & 22 & 23 \\
\hline $55-64$ yrs & 09 & 09 \\
\hline$>65$ yrs & 01 & 01 \\
\hline Place of residence & Frequency & Percentage \\
\hline Rural & 66 & 68 \\
\hline Urban & 31 & 32 \\
\hline Socio-Economic Status (SES) Scale $*$ & Frequency & Percentage \\
\hline I & 05 & 05 \\
\hline
\end{tabular}




\begin{tabular}{|c|c|c|}
\hline II & 09 & 09 \\
\hline III & 32 & 33 \\
\hline IV & 44 & 45 \\
\hline $\mathbf{V}$ & 07 & 07 \\
\hline Religion & Frequency & Percentage \\
\hline Christian & 11 & 11 \\
\hline Hindu & 79 & 81 \\
\hline Muslim & 07 & 07 \\
\hline Occupation $^{\#}$ & Frequency & Percentage \\
\hline Low Skilled Workers & 13 & 13 \\
\hline Unskilled Workers & 34 & 35 \\
\hline Medium Skilled Workers & 20 & 21 \\
\hline Unemployed & 30 & 31 \\
\hline Marital Status & Frequency & Percentage \\
\hline Single & 06 & 06 \\
\hline Married & 87 & 90 \\
\hline Widow & 01 & 01 \\
\hline Divorcee & 01 & 01 \\
\hline Separated & 02 & 02 \\
\hline Educational Status & Frequency & Percentage \\
\hline Illiterates & 28 & 29 \\
\hline Primary School & 41 & 42 \\
\hline Secondary School & 12 & 12 \\
\hline Intermediate & 06 & 06 \\
\hline Graduate & 07 & 07 \\
\hline Post Graduate & 03 & 03 \\
\hline Total & 97 & 100 \\
\hline
\end{tabular}

Among the study participants, majority were males accounting for $68 \%$ of the total subjects and majority (67\%) of them belong to economically productive age group "15-44 Years" while 33\% belong to age group "45 and above". Most of the MDR-TB patients (68\%) belong to "rural" background. Most (85\%) of the study subjects belong to the lower SES (Class III, IV \& V) as per modified BG Prasad SES Scale. Majority (81\%) of the study subjects belong to the "Hindu Religion". About 35\% of MDR-TB patients belong to "Unskilled" occupation group while $31 \%$ belong to "Unemployed" occupation group. "Medium" and "Low" Skilled Occupation was present in $21 \%$ and $13 \%$ of the Study subjects. None of the study subjects belong to "Highly Skilled" occupation group. Majority of the study subjects were "married" (88\%) in the study. The educational status was below primary level in $71 \%$ of the study subjects while the rest $(29 \%)$ had the educational status of more than secondary level.

Table 3: Factors responsible for diagnostic delay of MDR-TB patients

\begin{tabular}{|c|c|c|c|c|c|c|c|c|}
\hline \multirow[t]{2}{*}{ Variable } & \multicolumn{2}{|c|}{ Diagnosis } & \multirow{2}{*}{$\begin{array}{c}\text { Frequency } \\
(\mathbf{n}=97)\end{array}$} & \multirow[t]{2}{*}{$\%$} & \multirow{2}{*}{$\begin{array}{c}\text { Chi- } \\
\text { square }\end{array}$} & \multirow{2}{*}{ df } & \multirow{2}{*}{$\begin{array}{c}\text { p- } \\
\text { value }\end{array}$} & \multirow[t]{2}{*}{ Inference } \\
\hline & $\begin{array}{l}\leq 14 \\
\text { Days }\end{array}$ & $\begin{array}{c}>14 \\
\text { Days }\end{array}$ & & & & & & \\
\hline \multicolumn{9}{|l|}{ Age } \\
\hline$<45$ Years & 20 & 45 & 65 & 67 & \multirow[t]{2}{*}{0.128} & \multirow[t]{2}{*}{1} & \multirow[t]{2}{*}{0.72} & \multirow{2}{*}{$\begin{array}{c}\text { Not } \\
\text { Significant }\end{array}$} \\
\hline$>45$ Years & 11 & 21 & 32 & 33 & & & & \\
\hline $\begin{array}{l}\text { Distance of Sample Collection Centre } \\
\text { (SCC) from Patients Residence }\end{array}$ & & & & & \multirow[t]{3}{*}{15.97} & \multirow[t]{3}{*}{1} & \multirow[t]{3}{*}{$\begin{array}{c}<0.00 \\
1\end{array}$} & \multirow[t]{3}{*}{$\begin{array}{c}\text { Highly } \\
\text { Significant }\end{array}$} \\
\hline$>10 \mathrm{Kms}$ & 11 & 51 & 62 & 63 & & & & \\
\hline$<10 \mathrm{Kms}$ & 20 & 15 & 35 & 37 & & & & \\
\hline \multicolumn{5}{|l|}{ Co-morbid condition } & \multirow[t]{3}{*}{31.7} & \multirow[t]{3}{*}{1} & \multirow{3}{*}{$\begin{array}{c}<0.00 \\
1\end{array}$} & \multirow{3}{*}{$\begin{array}{c}\text { Highly } \\
\text { Significant }\end{array}$} \\
\hline Present & 07 & 54 & 61 & 65 & & & & \\
\hline Absent & 24 & 12 & 36 & 35 & & & & \\
\hline Alcohol Consumption & & & & & \multirow[t]{3}{*}{8.35} & \multirow[t]{3}{*}{1} & \multirow{3}{*}{$\begin{array}{c}<0.00 \\
1\end{array}$} & \multirow{3}{*}{$\begin{array}{c}\text { Highly } \\
\text { Significant }\end{array}$} \\
\hline Absent & 21 & 24 & 45 & 46 & & & & \\
\hline Present* & 10 & 42 & 52 & 54 & & & & \\
\hline Smoking Habit & & & & & \multirow[t]{2}{*}{0.783} & \multirow[t]{2}{*}{1} & \multirow[t]{2}{*}{0.37} & \multirow{2}{*}{$\begin{array}{c}\text { Not } \\
\text { Significant }\end{array}$} \\
\hline Absent & 23 & 46 & 69 & 71 & & & & \\
\hline
\end{tabular}


A Community Based Cross-Sectional Study To Find Out The Factors For The Delay In Diagnosis ...

\begin{tabular}{|c|c|c|c|c|c|c|c|c|}
\hline Present* & 12 & 16 & 28 & 29 & & & & \\
\hline Family Support & & & & & \multirow[t]{3}{*}{14.21} & \multirow[t]{3}{*}{1} & \multirow{3}{*}{$\begin{array}{c}<0.00 \\
1\end{array}$} & \multirow{3}{*}{$\begin{array}{c}\text { Highly } \\
\text { Significant }\end{array}$} \\
\hline Absent & 09 & 46 & 55 & 57 & & & & \\
\hline Present & 22 & 20 & 42 & 43 & & & & \\
\hline HIV status & & & & & \multirow[t]{3}{*}{0.11} & \multirow[t]{3}{*}{1} & \multirow[t]{3}{*}{0.74} & \multirow{3}{*}{$\begin{array}{c}\text { Not } \\
\text { Significant }\end{array}$} \\
\hline Negative & 27 & 59 & 86 & 89 & & & & \\
\hline Positive \& Unknown & 04 & 07 & 11 & 11 & & & & \\
\hline $\begin{array}{l}\text { Number of health facilities visited } \\
\text { before diagnosis }\end{array}$ & & & & & & & \multirow[t]{4}{*}{0.53} & \multirow[t]{4}{*}{$\begin{array}{c}\text { Not } \\
\text { Significant }\end{array}$} \\
\hline 1 & 17 & 36 & 53 & 55 & \multirow[t]{3}{*}{1.25} & \multirow[t]{3}{*}{2} & & \\
\hline 2 & 09 & 26 & 35 & 36 & & & & \\
\hline$\geq 3$ & 04 & 05 & 09 & 09 & & & & \\
\hline \multicolumn{9}{|l|}{ Gender } \\
\hline Female & 08 & 23 & 31 & 32 & \multirow[t]{2}{*}{0.793} & \multirow[t]{2}{*}{1} & \multirow[t]{2}{*}{0.373} & \multirow{2}{*}{$\begin{array}{c}\text { Not } \\
\text { Significant }\end{array}$} \\
\hline Male & 23 & 43 & 66 & 68 & & & & \\
\hline \multicolumn{9}{|l|}{ SES (Modified BG Prasad Scale) } \\
\hline Lower SES (CLASS III,IV \& V) & 14 & 46 & 60 & 62 & \multirow[t]{2}{*}{5.38} & \multirow[t]{2}{*}{1} & \multirow[t]{2}{*}{0.02} & \multirow[t]{2}{*}{ Significant } \\
\hline Upper SES (CLASS I \& II) & 17 & 20 & 37 & 38 & & & & \\
\hline \multicolumn{9}{|l|}{ Educational status } \\
\hline Primary and Below & 26 & 43 & 69 & 71 & \multirow[t]{2}{*}{3.6} & \multirow[t]{2}{*}{1} & \multirow[t]{2}{*}{0.05} & \multirow[t]{2}{*}{ Significant } \\
\hline Secondary and Above & 05 & 23 & 28 & 29 & & & & \\
\hline \multicolumn{9}{|l|}{ Occupational status } \\
\hline Unemployed & 12 & 18 & 30 & 31 & 1.29 & 1 & 0.25 & Not \\
\hline Employed & 19 & 48 & 67 & 69 & & & & Significant \\
\hline Area of Residence & & & & & & & & \\
\hline Rural & 21 & 45 & 66 & 68 & 0.002 & 1 & 0.965 & Not \\
\hline Urban & 10 & 21 & 31 & 32 & & & & Significant \\
\hline Religion & & & & & & & & \\
\hline Christian & 03 & 08 & 11 & 11 & 0.18 & 2 & 0.91 & Not \\
\hline Hindu & 26 & 53 & 79 & 81 & & & & Significant \\
\hline Muslim & 02 & 05 & 07 & 08 & & & & \\
\hline $\begin{array}{l}\text { Type of health facility first consult } \\
\text { before diagnosis }\end{array}$ & & & & & & & & \\
\hline Government & 19 & 41 & 60 & 62 & 0.82 & 2 & 0.66 & Not \\
\hline Medical College & 01 & 05 & 06 & 06 & & & & Significant \\
\hline Private & 11 & 20 & 31 & 32 & & & & \\
\hline
\end{tabular}

*indicates current and past status

The factors associated with diagnostic delay were long distance of Sputum collection centre (SCC) from patients residence; existence of co-morbid illness, alcoholism, low education level (below primary level), low monthly per capita income (lower SES) and lack of family support.

Table-4: Reasons for the Diagnostic Delay (Patient \& Health System Perception)

\begin{tabular}{|l|c|}
\hline $\begin{array}{l}\text { Reasons for Diagnostic Delay } \\
\text { (Patient Perception) }\end{array}$ & Frequency* \\
\hline Private Practitioner & 23 \\
\hline Lack of money & 12 \\
\hline Stigma & 12 \\
\hline Lost faith in TB Control Program & 05 \\
\hline Side effects fear & 05 \\
\hline Co-Morbid Conditions & 04 \\
\hline Unco-operative family members & 01 \\
\hline $\begin{array}{l}\text { Reasons for Diagnostic Delay } \\
\text { (Health System Perception) }\end{array}$ & \\
\hline Lack of logistics \& courier & 43 \\
\hline STLS vacancy & 10 \\
\hline Sputum negative result at IRL & 4 \\
\hline Improper collection of sputum & 3 \\
\hline Lack of counselling & 1 \\
\hline
\end{tabular}

*includes multiple responses

\section{Discussion}

About $89 \%$ of study participants who had co-morbid illness were associated with delay in diagnosis and this association was found to be statistically significant which was also an independent risk variable for 
diagnostic delay in the study done by Jurcev-Savicevic A et al $(2012)^{5}$ and Mor Z et al (2013) ${ }^{6}$.With regard to the history of alcohol consumption, $81 \%$ of the study participants had diagnostic delay which was found to be statistically significant and was similar to the study findings of Storla DG et al (2008) ${ }^{7}$ and Rajeswari R et al $(2002)^{8}$. Studies done by Rajeswari R et al $(2002)^{8}$ and Makwakwa L et al (2014) ${ }^{9}$ reported that distance between patient's residence and sample collection centre has led to diagnostic delay and this finding is also consistent with the present study. As per the studies from Bai LQ et al (2004) ${ }^{10}$,Storla DG et al (2008) ${ }^{7}$ and Li Y et al $(2013)^{11}$, poverty is one of the important factors that is independently associated with delay in diagnosis. The present study findings also concur with the findings of these studies. Low socioeconomic status is associated with delay in diagnosis while socioeconomically better off participants were able to get diagnosed in time. In the present study, $84 \%$ of study participants who had no family support reported delay in diagnosis and this was association was statistically significant which was also found in the studies of Krishnan L et al (2014) ${ }^{12}$ and Sukumani J et al (2012) ${ }^{13}$. Study participants with a lower education status (less than primary level) reported that time taken for diagnosis was 15 days or more which was found to be statistically significant. This finding is consistent with the findings from the studies of Lusignani LS et al (2013) ${ }^{14}$ and Storla DG et al $(2008)^{7}$

Reasons for diagnostic delay - Patient's Perspective: the most important reasons that were reported by the patients were 1 . Consulting a private practitioner and getting misguided by them has led to substantial delay in diagnosis, 23 responses were recorded on this reason. 2. Lack of money is another important reason that came up during patient interviews that led to delay in diagnosis. Patients felt that timely financial support would have helped them to reach sample collection centre and provide samples promptly, 12 responses were recorded on this reason. 3. Stigma is the third important reason; especially among young married females who felt that identifying them as a TB patient would lead to divorce and collapse of the family, just because the family members are not well aware about the disease and its treatment aspects. The other reasons are lost faith in the TB control program, uncooperative family members and co-morbid conditions that were severe and made patient believe that TB is only secondary to their existing co- morbid illness.

Reasons for diagnostic delay - Health care system perspective: From the health care system point of view, the important reasons for delay in diagnosis is that for a short period of time there was deficit in logistic supply such as thermocol boxes, gel packs and falcon tubes to transport the samples from sample collection centre to C\&DST Laboratory (IRL) - 43 responses were recorded on this reason. The second important reason that was perceived by the health care staff was prolonged vacancy of STLS. This position is key at TU level in preparation of MDR-TB suspect line-list, ensure training of LTs at the DMCs and presence of logistics for sputum collection \& transportation. Since there was a vacancy existed in 2 TUs, most of the work was hampered and resulted in delay. This is followed by the reasons such as declaration of smear negative at IRL that led to submission of those samples to solid media culture which obviously delay in report of the result. The other reason being improper sputum collection that led to rejection of the sample at IRL, either contamination or leakage of the sample.

\section{Conclusion}

In the present study, factors associated with diagnostic delay were long distance of Sputum collection centre (SCC) from patients residence; existence of co-morbid illness, alcoholism, low education level (below primary level), low monthly per capita income (lower SES) and lack of family support.

\section{Recommendations}

Decentralization of Sputum collection centre (SCCs) to PHC level from the existing DMC level, Immediate recruitment of the vacancies of Key staff, timely procurement and ensuring availability of the logistics at the field level, health education to patients to adopt a healthy life style to abstain them from harmful risk factor like alcoholism and linking the TB programme to relevant services for co-morbid conditions would decrease the diagnostic delay.

\section{Acknowledgements}

We greatly acknowledge the support and co-operation of the entire staff of District TB Control Office Krishna District, AP and the study participants.

\section{References}

[1]. World Health Organization. Global TB report. Geneva: WHO; 2013.

[2]. Dixit AK, Chaudhary E and Dixit J. Programmatic management of Drug Resistant Tuberculosis: A new chapter in the strategy of Revised National Tuberculosis Control Programme of India. National journal of Community Medicine. 2013; 4(3):541-544

[3]. Chadha SS, Sharath BN, Reddy K, Jaju J, Vishnu PH et al. Operational Challenges in Diagnosing Multi-Drug Resistant TB and Initiating Treatment in Andhra Pradesh, India. PLoS ONE. 2011; 6(11): e26659. 
[4]. Government of India. Guidelines on Programmatic Management of Drug Resistant TB (PMDT) in India. New Delhi: Central TB Division, Directorate General of Health Services, Ministry of Health and Family Welfare; 2012.

[5]. Jurcev-Savicevic A, Popovic-Grle S, Mulic R, Smoljaovic M, et al. Delays in diagnosing and treating tuberculosis in Croatia. Arh Hig Rada Toksikol. 2012; 63(3):385-394.

[6]. Mor Z, Kolb H, Lidji M, Migliori GB et al. Tuberculosis diagnostic delay and therapy outcomes of non-national migrants in Tel Aviv, 1998-2008 . Euro Surveill. 2013;18(12):e20433.

[7]. Storla DG, Yimer S and Bjune GA. A systematic review of delay in the diagnosis and treatment of tuberculosis.BMC Public Health 2008; 8:15.

[8]. Rajeswari R, Chandrasekaran V, Suhadev M, Sivasubramaniam S et al. Factors associated with patient and health system delays in the diagnosis of tuberculosis in South India. Int J Tuberc Lung Dis. 2002; 6(9):789-795.

[9]. Makwakwa L, Sheu ML, Chiang CY, Lin SL, et al .Patient and heath system delays in the diagnosis and treatment of new and retreatment pulmonary tuberculosis cases in Malawi. BMC Infect Dis. 2014; 14:132

[10]. Bai LQ, Xiao SY. Factors associated with diagnostic delay for patients with smear-positive pulmonary tuberculosis in rural Hunan, China. Zhonghua Jie He He Hu Xi Za Zhi 2004; 27(9):617-620.

[11]. Li Y, Ehiri J, Tang S, Li D et al. Factors associated with patient, and diagnostic delays in Chinese TB patients: a systematic review and meta-analysis. BMC Med. 2013; 11:156.

[12]. Krishnan L, Akande T, Shankar AV et al., "Gender-Related Barriers and Delays in Accessing Tuberculosis Diagnostic and Treatment Services: A Systematic Review of Qualitative Studies". Tuberculosis Research and Treatment. 2014, e215059, doi: $10.1155 / 2014 / 215059$.

[13]. Sukumani JT, Lebese RT, Khoza LB and Risenga PR. 'Experiences of family members caring for tuberculosis patients at home at Vhembe district of the Limpopo Province'. Curationis 2012, 35(1):1-8.

[14]. Lusignani LS, Quaglio G, Atzori A, Nsuka J et al. Factors associated with patient and health care system delay in diagnosis for tuberculosis in the province of Luanda, Angola. BMC Infect Dis. 2013; $13(1): 168$.

[15]. SK Sasikumar, AK Karan. Skill Mapping in Indian Labour Market: Supply Side Potential and Emerging Demand Scenario. Labour \& Development [Internet] 2010;16-17(2):22-24. [cited on 12 Mar 2014]. Available from: http://www.vvgnli.org/sites/default/files/publication_files/Skill\%20Mapping\%20in\%20Indian\%20Labour\%20Market.pdf 